\title{
Moscow 2002
}

\author{
By Ron Holloway
}

Fall 2002 Issue of KINEMA

MOSCOW INTERNATIONAL FILM FESTIVAL 2002

Some highly plausible reasons were given by the organizers of the 24th Moscow International Film Festival (21-30 June 2002) for scaling down the budget to approximately half of last year's 3 million rubles (circa $\$ 1$ million as fluctuating exchange rates go). According to one insider, the budget remained the same as before, but some outstanding debts from previous years had not yet been paid off. Also, since a blowout festival is planned for the $25^{\text {th }}$ anniversary in 2003, the 24th outing was stylized as a modest showcase of better things to come.

Nikita Mikhalkov, MIFF's president, opened and closed the festival in Gorky Park, on the very spot where he has regularly expressed hopes to erect a festival headquarters of appropriate representative proportions in the near future. Hollywood VIPs -- Bob Rafelson, Harvey Keitel, Holly Hunter, among others -- were invited to breakfast with President Vladimir Putin. General director Renat Davletyarov was given a complete bill of operating health by FIAPF's general secretary Phyllis Mollet. And programming director Kirill Razlogov corrected last year's oversight by inviting no less than three Russian films to compete for the St. George Statuette.

Despite the improvements, however, festival regulars expressed feelings that Moscow is still too mired in the traditions of the past and thus has a long way to go before it can boast of a festival niche between Cannes and Venice as the premiere mid-summer film event on the calendar. In fact, two other Russian international festivals, Sochi to the south and St. Petersburg to the north, contend for the same quality Russian fare -- and both are scheduled before Moscow. Indeed, it was St. Petersburg that bagged Alexander Sokurov's Russian Ark, the Cannes entry that was "one-shot" in the Hermitage and Winter Palace with a cast of thousands. Furthermore, the Karlovy Vary festival, scheduled on the heels of Moscow, grows annually in prestige as more deluxe hotels open in one of Europe's favourite spas to house comfortably an increasing numbers of media professionals, some of whom had been "miffed" by MIFF this year.

Moscow's strength is its broad range of entries programmed in separate sections by curators who know their film history and have toured the major festivals. Besides the Main Program, the responsibility of Kirill Razlogov, the Panorama featured Special Screenings, Previews, Debut Filmmakers, Trends in World Cinema, Contemporary Russian Cinema, National Hits, Norwegian Cinema Today, Exotica (fringe cultures), Afghan Knot (films on Afghanistan), and Retrospective Tributes -- to Bob Rafelson, Stanley Kubrick, Roger Vadim, Grigory Chukhrai, and Unknown (Boris) Barnet.

Provided you knew your way through the metro labyrinth, a veritable feast of world cinema was at your beck and call at scattered venues around the city. But you didn't have to go far to catch the Unknown Barnet shows: some screenings took place in the newly installed Film Club under the roof of the Manezh, the city's exhibition hall housing the festival headquarters.

Resurrezione (Italy /France /Germany), a cumbersome two-part tv adaptation by Paolo and Vittorio Taviani of Tolstoy's Resurrection (publ. 1899), was awarded the St. George Statuette by an international jury headed by writer-diplomat Chingiz Aitmatov. Previously rejected by Cannes and Venice, the updated version with an international cast didn't fare much better than the original Mikhail Shvejcer (Moisei Schweitzer) version filmed 40 years ago in 1961 as a two-part spectacle with socialist realist leanings. Timothy Peach plays Prince Neckliudov in love with Katya Maslova (Stefania Rocca), a prostitute accused of theft and murder, who had previously worked as a servant girl at his aunt's villa and had been compromised by the young nobleman.

For the second year in a row, the Special Jury Prize was awarded to an Iranian entry. Vahid Mousaian's Are zou-ha-ye zamin (Wishes of the Land), a debut feature film by a documentary filmmaker, is the tragic story of a young girl in a rural community who defies tradition by rejecting the family's chosen husband to decide for herself whom she wants to marry, in this case a sensitive young shepherd. 
Along similar lines, Monika Krzywkowska, awarded Best Actress, plays a young woman who wins the affection of a young man wrestling with a dubious vocation to the priesthood in Krzysztof Zanussi's Suplement (Supplement, Poland), the title referring to Zanussi's desire to retell the same story written for his previous feature, Life As a Fatal Sexually Transmitted Disease (2000), this time from the perspective of the woman. Supplement also shared the FIPRESCI (International Critics) Prize.

As for the best film on view at MIFF, Alexander Rogozhkin's Kukushka (Cuckoo, Russia) well deserved its multiple citations -- Best Director Award, the FIPRESCI (International Critics) Prize, and the Audience Award -- and should have walked away with the St. George Statuette as well. Set in September of 1944 in the idyllic Lapp country of northern Finland, the tale features three individuals -- a Russian and a Finn (Willie Haapsalo, Best Actor Award), both soldiers, and a Lapp woman, who lost her husband in the war -- in an hilarious tragicomedy of mutual misunderstandings in the days just before Finland and the Soviet Union signed a peace agreement. Witty dialogue, humorous narrative twists, and a real discovery in Anni-Kristina Usso, a non-professional Lapp, assure that Cuckoo will find an audience worldwide.

Another festival highlight was the world premiere of Bob Rafelson's The House on Turk Street (USA /Canada /Germany), a bizarre film noir adaptation of a short story by Dashiell Hammett with Samuel L. Jackson as a detective with diabetes and Milla Jovovich as a Russian gunmoll-pianist with a yen for classical music. And Arvo Iho's Karu Suda (Heart of the Bear, Estonia /Russia /Germany /Czech Republic) confirms once again how the wilds of Siberia can inspire an accomplished cinematographer (Estonia's Rein Kotov).

\section{References}

\section{AWARDS}

International Competition

St. George Statuette (Grand Prix): Resurrezione (Resurrection, Italy /France /Germany), Paolo and Vittorio Taviani

Special Jury Prize: Are zou-ha-ye zamin (Wishes of the Land, Iran), Vahid Mousaian

Best Director: Kukushka (Cuckoo, Russia), Alexander Rogozhkin

Best Actress: Monika Krzywkowska, Suplement (Supplement, Poland), Krzysztof Zanussi

Best Actor: Willie Haapsalo, Kukushka (Cuckoo, Russia), Alexander Rogozhkin

Special Awards: actor Harvey Keitel

International Critics (FIPRESCI) Prize -- ex aequo

Kukushka (Cuckoo, Russia), Alexander Rogozhkin

Suplement (Supplement, Poland), Krzysztof Zanussi

Russian Critics Prize

Chehovskie motivy (Chekhov's Motives, Russia /Ukraine), Kira Muratova

Russian Federation of Film Clubs Award

Kukushka (Cuckoo, Russia), Alexander Rogozhkin

Pisma k Elza (Letters to Elza, Russian), Igor Maslennikov

Audience Award

Kukushka (Cuckoo, Russia), Alexander Rogozhkin

Best Debut Film (Kodak Prize)

Are zou-ha-ye zamin (Wishes of the Land, Iran), Vahid Mousaian 


\section{Author Information}

Ron HOLLOWAY (1933-2009) was an American critic, film historian, filmmaker and correspondent who adopted Europe as his home in the early fifties and spent much of his life in Berlin. He was an expert on the study of German cinema and against all odds produced, with his wife Dorothea, the journal German Film, keeping us up-to-date with the work of directors, producers and writers and the showing of German films around the world.

In 2007, Ron Holloway and his wife were awarded the Berlinale Camera Award. Ron also received the Bundesverdienstkreuz (German Cross of Merit), Polish Rings, Cannes Gold Medaille, the American Cinema Foundation Award, the Diploma for Support of Russian Cinema and an honorary award from the German Film Critics' Association.

Ron was also a valued contributor to Kinema for the past fifteen years. 